\title{
Bovine Coronavirus (BoCV) Infection in Calves with Diarrhoea and Their Dams
}

\author{
Sibel Yavru', Orhan Yapici', Mehmet Kale'2, Sima Sahinduran³, \\ Faruk Pehlivanoglu ${ }^{4}$, Metın Koray Albay ${ }^{3} \&$ Oguzhan Avci ${ }^{1}$
}

\begin{abstract}
Background: Bovine coronavirus (BoCV) is common with high seroprevalence in dairy cattle. It is reported in many countries. Also, BoCV causes diarrhea in dairy calves. The transmission of BoCV is the fecal-oral/aerosol-nasal routes. Feces from clinical cases or clinically normal dairy cattle are source of infection, also contamination of feed and water. The purpose of the current study was to investigate BoCV infection in diarrheic calves (age and sex) and their dams (age). For this reason, the serological and virological methods were used. Haematological parameters of the calves and their dams were compared using the statistical methods.

Materials, Methods \& Results: In this study, following clinical examination of 3500 cattle and their calves from 25 number of dairy farms 184 calves with diarrhoea and their dams (183) ( $\geq 2-\leq 6$ age) were sampled for BoCV presence by enzyme linked immunosorbent assay (ELISA). Additionally, all blood samples were examined by hematological methods. $172(93.99 \%)$ cows and $172(93.99 \%)$ calves were found antibodies $(\mathrm{Ab})$ positive $(+)$. The high levels of $\mathrm{Ab}$ for BoCV were detected as $36.05 \%$ in dams 6 years and older ages. In the calves, $\mathrm{Ab}$ to BoCV were found at the highest level (25.26\%) in the female calves $\geq 5-\leq 6$ months ages. BoCV antigen (Ag) was detected in only faecal sample of a $(0.54 \%)$ calf. When the haematological parameters were compared between $\mathrm{BoCV} \mathrm{Ab}(+)$ and BoCV Ab negative (-) dams, only white blood cell (WBC) values were found statistically significant $(P<0.05)$. When the haematological parameters were compared between $\mathrm{BoCV} \mathrm{Ab}(+) / \mathrm{Ag}(-)$ and $\mathrm{BoCV} \mathrm{Ab}(-) / \mathrm{Ag}(-)$ calves, WBC $(P<0.05)$, lymphocyte $(P<0.01)$ and granulocyte $(\mathrm{P}<0.01)$ values were found statistically important. When the haematological parameters were compared between $\mathrm{BoCV} \mathrm{Ab} \mathrm{(+)/Ag} \mathrm{(+)} \mathrm{and} \mathrm{BoCV} \mathrm{Ab}(-) / \mathrm{Ag}(-)$ calves, both lymphocyte and granulocyte values were statistically important $(P<0.01)$.

Discussion: $\mathrm{BoCV}$ infection has found worldwide among cattle of all ages. The disease results in major economic losses in dairy herds that result from treatment costs and calf deaths. One hundred seventy two out of 183 mothers whose blood sampling was done were detected as seropositive. Many researchers found similar results in dairy cattle. It was detected the highest seropositivity in cattle more than six years old. One hundred seventy two blood samples out of 184 calves were detected seropositive. Also, the highest seropositivity was detected among of $>$ 5 and $<6$ months of age. BoCV Ag (+) presence was detected in only one faecal sample of one calf out of 184 . Researchers were found same or higher $\mathrm{BoCV} \mathrm{Ag}(+)$ rates in faeces of diarrheic calves. In the study lymphocyte counts of seropositive cows and in $\mathrm{Ab}(+) / \mathrm{Ag}(+)$ calves determined decrease. However, the counts in seropositive calves were increased. Leukocytes levels were also high in seropositive calves. Haematocrit values were decreased in seropositive cows, calves and in $\mathrm{Ab}(+) / \mathrm{Ag}(-)$ calves. BoCV infections were detected at low level in diarrheic calves. But, BoCV seropositive mature and diarrheic calves were found at high levels. Haematological application methods could be used to be supportive with the serological and virological methods. All farm managements should be maintained with strict hygiene practices. Milking bottle, calf pens or hutches need to be sanitized. The calves must be prevent contamination from faeces and urine of other calves. The protective vaccination must be applied all animals.
\end{abstract}

Keywords: coronavirus, dairy cattle, calf diarrhoea, haematology, serology, virology. 


\section{INTRODUCTION}

Bovine coronavirus (BoCV) infections are seen widely all over the world and cause great economical losses. In general, the virus effects cattle in three different ways and causes clinical syndromes. This interaction appears as diarrhoea in calves, winter dysentery in mature cattle and respiratory system infections in various aged cattle [1]. Coronaviruses have affinity with small and large intestine and upper respiratory system [27]. The virus replicates after it enters the organism and causes infection. Compared to calves dying greatly of diarrhoea, mortality in viruseffected dysenteric mature cattle is rare [19]. But not only dysenteric mature cattle but also healthy looking mature cattle could spread the virus around by their faeces. This condition could produce a scene resulted with infection of susceptible calves $[8,10]$. BoCV infection generally appears as the result of orally taking of food or water contaminated with infected faeces. The virus is also able to cause infection by faecal-oral way. However, some researchers claim that the virus can also cause infection by aerosol ways $[16,30]$. The infection is more effective and common during winter months.

In this study, BoCV infection presence in various aged diarrheic calves from dairy cattle plants and their clinically healthy looking mothers was studied serologically, virologically and haematologically.

\section{MATERIALS AND METHODS}

\section{Faecal samples}

Faecal samples were collected from 184 calves, located in 25 private cattle raising plants in Burdur, and showing diarrhoea symptoms as a result of a clinical inspection. Faecal samples brought into laboratories under cold chain were kept at $-80^{\circ} \mathrm{C}$ until they were studied.

\section{Sera samples}

Blood samples were collected from 184 calves and their mothers, located in 25 private cattle raising plants in Burdur, and showing diarrhoea symptoms as a result of a clinical inspection. Blood samples taken into sterile vacuum tubes ${ }^{1}$ collected for serological testing were brought into laboratories under cold chain and centrifuged at $720 \mathrm{~g}$ for $10 \mathrm{~min}$ and then taken into sterile Eppendorf tubes ${ }^{2}$. Serum samples inactivated in $56^{\circ} \mathrm{C}$ water bath for $30 \mathrm{~min}$ were kept at $-80^{\circ} \mathrm{C}$ until testing.
Haematology

To detect haematological blood parameters, blood samples from 184 calves and their mothers were taken into 2 mL EDTA tubes ${ }^{1}$. To detect haematological parameters in these samples, blood meter ${ }^{3}$ was used. Samples were studied within the same day.

\section{Enzyme linked immunosorbent assay (ELISA)}

Faecal samples from the calves were studied by direct $\mathrm{ELISA}^{4}$ for BoCV antigen (Ag) presence. And serum samples from the calves and their mothers were studied by indirect ELISA ${ }^{4}$ for BoCV antibodies (Ab) presence. The tests were applied according to the testing procedure of the producing company.

\section{Statistical analysis}

During the evaluations, $t$ test was used to compare intergroup blood values in mothers as $\mathrm{Ab}$ positive (+) and $\mathrm{Ab}$ negative (-), and in calves as $\mathrm{Ab}(+) / \mathrm{Ag}$ $(-)$ and $\mathrm{Ab}(-) / \mathrm{Ag}(-), \mathrm{Ab}(+) / \mathrm{Ag}(-)$ and $\mathrm{Ab}(-) / \mathrm{Ag}(-)$. One-way analysis of variance (One-way ANOVA) was applied for intergroup comparison by means of blood values in mothers and calves. In statistical analysis, SPSS $^{5}$ package program was used.

\section{RESULTS}

The highest $\mathrm{BoCV} \mathrm{Ab} \mathrm{(+)/Ag} \mathrm{(-)} \mathrm{presence}$ $(25.26 \%)$ was detected in 5 and older $\& 6$ and younger month-old female calves and the lowest BoCV Ab (+)/ $\mathrm{Ag}(-)$ presence (11.69\%) was detected in 2 and older $\&$ younger than 4 month-old male calves (Table 1). One hundred seventy two (93.99\%) calves and 172 (93.99\%) mothers were detected as $\mathrm{Ab}(+)$. For mothers more than 6 years old, the highest $\mathrm{BoCV} \mathrm{Ab}(+)$ presence $(36.05 \%)$ was detected (Table 2). From 184 faecal samples of calves studied by direct ELISA, BoCV Ag (+) presence was detected in only one faecal sample $(0.54 \%)$.

In comparing haematological parameters of cows (mothers) having $\mathrm{BoCV} \mathrm{Ab} \mathrm{(+)} \mathrm{and} \mathrm{BoCV} \mathrm{Ab}$ $(-)$, only the rates of white blood cell (WBC) average were found statistically important $(P<0.05)$, and the rate of $\mathrm{WBC}$ average in $\mathrm{BoCV} \mathrm{Ab}(+)$ group was found high when compared to BoCV Ab (-) group (Table 3). In comparing haematological parameters of calves (youngsters) having $\mathrm{BoCV} \mathrm{Ab}(+) / \mathrm{Ag}(-)$ and $\mathrm{BoCV}$ $\mathrm{Ab}(-) / \mathrm{Ag}(-)$, the rates of WBC, lymphocyte and granulocyte averages were found statistically important $(P<0.05$ and $P<0.01)$. While granulocyte average rate in $\mathrm{BoCV} \mathrm{Ab}(+) / \mathrm{Ag}(-)$ group was found low when 
compared to BoCV Ab (-)/Ag (-) group, WBC and lymphocyte average rate was found high (Table 3).

In the comparison which was done according to haematological parameters of calves (youngsters) having $\mathrm{BoCV} \mathrm{Ab}(+) / \mathrm{Ag}(+)$ and $\mathrm{BoCV} \mathrm{Ab}(-) / \mathrm{Ag}(-)$, lymphocyte and granulocyte average rates were found important $(P<0.01)$. While the lymphocyte average rate in $\mathrm{BoCV} \mathrm{Ab}(+) / \mathrm{Ag}(-)$ group was found lower than $\mathrm{BoCV} \mathrm{Ab}(-) / \mathrm{Ag}(-)$ group, the granulocyte average rate was found high (Table 4).

Table 1. Distribution of diarrheic calves having BoCV Ab (+)/Ag (-) and $\mathrm{Ab}(-) / \mathrm{Ag}(-)$ according to age and gender.

\begin{tabular}{|c|c|c|c|c|}
\hline \multirow{2}{*}{ Months } & \multicolumn{2}{|c|}{$\mathrm{Ab}(+) / \mathrm{Ag}(-)$} & \multicolumn{2}{|c|}{$\mathrm{Ab}(-) / \operatorname{Ag}(-)$} \\
\hline & $\hat{0}$ & ㅇ & 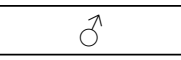 & q \\
\hline$<1$ & $11(14.29 \%)$ & $14(14.74 \%)$ & - & $1(20.0 \%)$ \\
\hline$\geq 1$ and $<2$ & $14(18.18 \%)$ & $14(14.74 \%)$ & - & - \\
\hline$\geq 2$ and $<3$ & $9(11.69 \%)$ & $12(12.63 \%)$ & - & $1(20.00 \%)$ \\
\hline$\geq 3$ and $<4$ & $9(11.69 \%)$ & $17(17.89 \%)$ & $1(16.67 \%)$ & $1(20.00 \%)$ \\
\hline$\geq 4$ and $<5$ & $15(19.48 \%)$ & $14(14.74 \%)$ & $3(50.00 \%)$ & $1(20.00 \%)$ \\
\hline$\geq 5$ and $\leq 6$ & $19(24.67 \%)$ & $24(25.26 \%)$ & $2(33.33 \%)$ & $1(20.00 \%)$ \\
\hline Subtotal & $77(46.77 \%)$ & $95(55.23 \%)$ & $6(54.55 \%)$ & $5(45.45 \%)$ \\
\hline Total & \multicolumn{2}{|c|}{$172(93.99 \%)$} & \multicolumn{2}{|c|}{$11(6.01 \%)$} \\
\hline
\end{tabular}

Table 2. Distribution of $\mathrm{BoCV} \mathrm{Ab}(+)$ and $\mathrm{Ab}(-)$ mothers according to age.

\begin{tabular}{ccc}
\hline Ages & $\mathrm{Ab}(+)$ & $\mathrm{Ab}(-)$ \\
\hline$\geq 2$ and $<3$ & $19(11.05 \%)$ & $1(9.09 \%)$ \\
$\geq 3$ and $<4$ & $25(14.53 \%)$ & $1(9.09 \%)$ \\
$\geq 4$ and $<5$ & $47(27.32 \%)$ & $4(36.37 \%)$ \\
$\geq 5$ and $<6$ & $19(11.05 \%)$ & $3(27.27 \%)$ \\
$\geq 6$ and over & $62(36.05 \%)$ & $2(18.18 \%)$ \\
\hline Total & $172(93.99 \%)$ & $11(6.01 \%)$ \\
\hline
\end{tabular}

Table 3. Statistical analysis of haematological parameters for cows and their calves with coronavirus $\mathrm{Ab}(+) / \mathrm{Ag}(-)$ and $\mathrm{Ab}(-) / \mathrm{Ag}(-)$.

\begin{tabular}{|c|c|c|c|c|c|c|c|c|}
\hline Cows & $\begin{array}{c}\text { WBC } \\
\left(10^{9} / \mathrm{L}\right)\end{array}$ & Lym. (\%) & Mon. (\%) & Gran. (\%) & $\begin{array}{c}\mathrm{RBC} \\
\left(10^{12} / \mathrm{L}\right) \\
\end{array}$ & Hct. (\%) & Hgb. (g/L) & Plt. $\left(10^{9} / \mathrm{L}\right)$ \\
\hline $\begin{array}{l}\mathrm{Ab}(+) \\
\mathrm{N}: 172\end{array}$ & $21.52 \pm 1.79$ & $54.34 \pm 3.85$ & $8.70 \pm 0.34$ & $35.29 \pm 1.14$ & $6.79 \pm 0.68$ & $35.08 \pm 0.30$ & $10.93 \pm 0.16$ & $289.68 \pm 14.26$ \\
\hline $\begin{array}{l}\mathrm{Ab}(-) \\
\mathrm{N}: 11\end{array}$ & $15.20 \pm 2.30$ & $55.99 \pm 1.34$ & $9.11 \pm 1.05$ & $36.58 \pm 2.94$ & $7.23 \pm 0.22$ & $36.01 \pm 0.81$ & $10.91 \pm 0.47$ & $295.00 \pm 39.42$ \\
\hline$P$ & $0.040 *$ & $0.693^{\mathrm{NS}}$ & $0.722^{\mathrm{NS}}$ & $0.688^{\mathrm{NS}}$ & $0.079^{\mathrm{NS}}$ & $0.304^{\mathrm{NS}}$ & $0.972^{\mathrm{NS}}$ & $0.901^{\mathrm{NS}}$ \\
\hline Calves & $\begin{array}{c}\text { WBC } \\
\left(10^{9} / \mathrm{L}\right)\end{array}$ & $\begin{array}{l}\text { Lym. } \\
(\%)\end{array}$ & $\begin{array}{l}\text { Mon. } \\
(\%)\end{array}$ & $\begin{array}{l}\text { Gran. } \\
(\%)\end{array}$ & $\begin{array}{c}\text { RBC } \\
\left(10^{12} / \mathrm{L}\right)\end{array}$ & $\begin{array}{l}\text { Hct. } \\
(\%)\end{array}$ & $\begin{array}{l}\text { Hgb. } \\
(g / L)\end{array}$ & $\begin{array}{c}\text { Plt. } \\
\left(10^{9} / \mathrm{L}\right)\end{array}$ \\
\hline $\begin{array}{c}\mathrm{Ab}(+) / \mathrm{Ag}(-) \\
\mathrm{N}: 172\end{array}$ & $33.38 \pm 8.04$ & $66.23 \pm 1.15$ & $9.42 \pm 0.36$ & $24.28 \pm 0.91$ & $10.19 \pm 0.13$ & $36.27 \pm 0.46$ & $10.86 \pm 1.99$ & $218.80 \pm 11.85$ \\
\hline $\begin{array}{c}\mathrm{Ab}(-) / \mathrm{Ag}(-) \\
\mathrm{N}: 11\end{array}$ & $14.25 \pm 1.73$ & $59.55 \pm 1.67$ & $10.39 \pm 0.77$ & $30.13 \pm 1.31$ & $10.69 \pm 0.52$ & $39.07 \pm 1.64$ & $10.59 \pm 0.46$ & $196.72 \pm 46.89$ \\
\hline$P$ & $0.021 *$ & $0.003 * *$ & $0.286^{\mathrm{NS}}$ & $0.001 * *$ & $0.368^{\mathrm{NS}}$ & $0.127^{\mathrm{NS}}$ & $0.590^{\mathrm{NS}}$ & $0.657^{\mathrm{NS}}$ \\
\hline
\end{tabular}

$* P<0.05 ; * * P<0.01 ;$ NS: Not Significant. 
Table 4. Statistical analysis of haematological parameters for calves with coronavirus $\mathrm{Ab}(+) / \mathrm{Ag}(+)$ and $\mathrm{Ab}(-) / \mathrm{Ag}(-)$.

\begin{tabular}{ccccccccc}
\hline Calves & $\begin{array}{c}\text { WBC } \\
\left(10^{9} / \mathrm{L}\right)\end{array}$ & Lym. $(\%)$ & Mon. $(\%)$ & Gran. $(\%)$ & $\begin{array}{c}\text { RBC } \\
\left(10^{12} / \mathrm{L}\right)\end{array}$ & Hct. (\%) & Hgb. (g/L) & $\begin{array}{c}\text { Plt. } \\
\left(10^{9} / \mathrm{L}\right)\end{array}$ \\
\hline $\begin{array}{c}\mathrm{Ab}(+) / \mathrm{Ag}(+) \\
\mathrm{N}: 1\end{array}$ & 12.59 & 39.80 & 13.50 & 46.70 & 9.70 & 37.40 & 10.30 & 359.00 \\
$\begin{array}{c}\mathrm{Ab}(-) / \mathrm{Ag}(-) \\
\mathrm{N}: 11\end{array}$ & $14.25 \pm 1.73$ & $59.55 \pm 1.67$ & $10.36 \pm 0.77$ & $30.14 \pm 1.31$ & $10.70 \pm 0.52$ & $39.07 \pm 1.64$ & $10.59 \pm 0.46$ & $196.73 \pm 46.89$ \\
\hline $\mathrm{P}$ & $0.787^{\mathrm{NS}}$ & $0.007^{* *}$ & $0.269^{\mathrm{NS}}$ & $0.004^{* *}$ & $0.593^{\mathrm{NS}}$ & $0.775^{\mathrm{NS}}$ & $0.859^{\mathrm{NS}}$ & $0.341^{\mathrm{NS}}$ \\
\hline${ }^{* *} P<0.01 ;$ NS: Not Significant. & & & & & &
\end{tabular}

\section{DISCUSSION}

BoCV is widely distributed in cattle populations in many countries. BoCV specific Ab can be found in a majority of adult animals [26]. BoCV is ubiquitous in cattle populations and the majority of adult cattle are seropositive [23]. In our study, 172 (93.99\%) out of 183 mothers whose blood sampling was done were detected as $\mathrm{Ab}(+)$. Similar results were also reported in mature cattle: $4.4-100 \%$ [3], $90 \%$ [21], 98.43\% [22] and 90\% [28]. However, there are researchers who detected lower results such as: $(82-86 \%)$ [5], (70\%) [9], (54.5\%) [16] and (26.3\%) [34]. Van Metre et al. [31] explained that the upper age limit of susceptibility to infection by BoCV is apparently longer than traditionally thought. The fact that in BoCV infection, the average infection age is higher than in some other infections is because coronavirus antibodies are secreted longer in milk, mothers are greatly infected with coronavirus in diarrheic herds and as they spread the virus especially on the day they give birth, the immune system is stimulated and immunoglobulin (Ig) is secreted from the mammary gland [32]. In one study BoCV seroprevalence in young (1-3 years) dairy cattle was lower than that of mature ones (>3-5 years) and the infection prevalence shows parallelism with increasing age [5]. Other report stated that from the blood serum samples of mature cattle, coronavirus seropositivity rate was the highest (54.3\%) in 5 old animals and they detected seropositivity at a rate of $49.7 \%$ in cattle more than six years old [33]. The same researchers claimed that female cattle show a higher seropositivity than male ones. In our study, in a completely female population, we detected the highest $\mathrm{Ab}(+)[36.05 \%]$ in cattle more than six years old.

In this study, 172 (93.99\%) blood samples out of 184 calves (one twins) were detected as $\mathrm{Ab}$ (+)/Ag (-). Another research detected 90.6\% BoCV seropositivity in 128 calves [4]. Also the coronavirus seropositivity level as $72 \%$ and $100 \%$ in calves were detected from three different regions [4]. Coronavirus and rotavirus seropositivity were observed between $80-100 \%$ in mature cattle and calves [15]. Thomas et al. [29] detected high titres of antibody in blood samples of calves for which they detected low rates of $\mathrm{BoCV} \mathrm{Ag} \mathrm{presence} \mathrm{in} \mathrm{feces}(1 \%)$ and nasal secretions $(2 \%)$ and low titres of antibodies in blood samples of calves for which they detected high rates of BoCV antibody presence in faeces $(65 \%)$ and nasal secretions $(64 \%)$. In our research, in blood serum samples of diarrheic calves, the highest $\mathrm{Ab}(+) /$ $\mathrm{Ag} \mathrm{(-)} \mathrm{(24.67 \%} \mathrm{for} \mathrm{males;} 25.26 \%$ for females) was detected among groups of $>5$ and $<6$ months of age. Literature reported that BoCV infection is seen more widely in calves older than three months of age, both healthy and diarrheic [22]. Antibodies are passed to the offspring via the colostrums; these are detectable in the sera until approximately 5-6 months of age, and can disturb the immune response to a natural infection $[2,17]$. The BoCV may be present in both diarrheic and healthy calves; the incidence rates range from 8-69\% and $0-24 \%$ for diarrheic calves and healthy calves respectively [23]. In the research, the fact that antibody levels of calves against $\mathrm{BoCV}$ at earlier ages were found lower than at later ages-that is; antibody levels were detected higher in later phases-could be because calves in sampled farms were kept with their mothers until 5-6 months of age and were kept together with mature ones after this age.

In our research, BoCV Ag (+) presence was detected in only one faecal sample of one calf (30 days of age) $(0.54 \%)$ out of 184 . Similar to the results of our study, BoCV Ag (+) was detected in faeces of diarrheic calves at a rate of $1.12 \%$ [6], 1\% [13], 1.4\% [15], 0.7\% [18], 1-3\% [20], 1.96\%. [22] and 1\% [29]. However, there are researchers who found higher BoCV Ag (+) rates in faeces of diarrheic calves: $38.9 \%$ [1], 20\% [7], $25.6 \%-37.1 \%$ [16] and 14\% [25]. BoCV causes 
diarrhoea in dairy calves, ranging in age from 1 day to 3 months but mostly between 1 and 2 weeks of age [5]. Calves have a high risk of BoCV infection within their first five weeks in life [1].

Dringeliene et al. [12] observed that the levels of erythrocytes, haemoglobin, total leukocytes and segmented neutrophils were decreased, while eosinophil and methemoglobin levels were increased in the blood of healthy and coronavirus-infected cows in the conventionally ecologically contaminated district. Viral infections are related to some alterations in the cellular and/or humoral immunity chain interaction in the organism [11,12]. Experimental infection of calves with virulent bovine coronavirus results in depletion of lymphocytes in the mesenteric lymph nodes and Peyer's patches, low levels of Igs and generalized immune suppression [24]. In this study lymphocyte counts of $\mathrm{Ab}(+)$ cows, and in $\mathrm{Ab}(+) / \mathrm{Ag}(+)$ calves showed decrease, which is in agreement with the immunosuppression hypothesis. But the lymphocyte counts in $\mathrm{Ab}$ $(+) / \mathrm{Ag}(-)$ calves were increased. It could have been due to another infection in any system of these calves. Leukocyte levels were also so high in $\mathrm{Ab}(+) / \mathrm{Ag}(-)$ calves that this was attributed to the high levels of lymphocyte in them. In this study, in $\mathrm{Ab}(+)$ cows, $\mathrm{Ab}$ (+) calves, and in $\mathrm{Ab}(+) / \mathrm{Ag}(+)$ calves, haematocrit values were decreased. A decreased haematocrit value can result from diarrhoea.

\section{CONCLUSION}

At the end of this study, while high levels of $\mathrm{BoCV} \mathrm{Ab} \mathrm{(+)} \mathrm{was} \mathrm{seen} \mathrm{in} \mathrm{mature} \mathrm{female} \mathrm{cows} \mathrm{and}$ diarrheic calves, BoCV Ag (+) presence was detected at highly low levels in diarrheic calves. We attribute this condition to the facts that hygienic measures were not carefully taken in establishments, there were subclinical infected mature-young cattle, feeding bottles used during feeding periods were not hygienic, and protective vaccination was not applied. We advise that the results obtained from haematological applications used to diagnose the infection can be used to be partially supportive.

\author{
MANUFACTURERS \\ ${ }^{1}$ Vacutest Kima S.R.L. Arzergrande, Italy. \\ ${ }^{2}$ Labor-Teknik. Istanbul, Turkey. \\ ${ }^{3}$ Cell Counter Equipment. Osny, France. \\ ${ }^{4}$ Bio-X Diagnostics. Rochefort, Belgium. \\ ${ }^{5}$ SPSS, SPSS10.0 for Windows (Standard version, 1989-1999).
}

Declaration of interest. The authors report no conflicts of interest. The authors alone are responsible for the content and writing of the paper.

\section{REFERENCES}

1 Abraham G., Roeder P.L. \& Zewdu R. 1992. Agents associated with neonatal diarrhoea in Ethiopian dairy calves. Tropical Animal Health and Production. 24(2): 74-80.

2 Alenius S., Niskanen R., Juntti N. \& Larsson B. 1991. Bovine coronavirus as the causative agent of winter dysentery: serological evidence. Acta Veterinaria Scandinavica. 32(2): 163-170.

3 Alkan F., Bilge-Dağalp S., Can Şahna K. \& Özgünlük İ. 2003. Sığırlarda coronavirus enfeksiyonunun epidemiyolojisi. Ankara Üniversitesi Veteriner Fakültesi Dergisi. 50(1): 59-64.

4 Alvarez M., Rubio P. \& Carmenes P. 1987. Prevalence of the infection caused by bovine coronavirus in the Northwest of Spain. Studies of the incidence and diffusion of the infection in calf fattening exploitations. Veterinarni Medicina. 4(3): 159-165.

5 Bidokhti M.R.M., Traven M., Fall N., Emanuelson U. \& Alenius S. 2009. Reduced likelihood of bovine coronavirus and bovine respiratory syncytial virus infection on organic compared to conventional dairy farms. The Veterinary Journal. 182(3): 436-440.

6 Çabalar M., Kaya A. \& Arslan S. 2007. Yeni do an buza ıların ishal olgularında rotavirus ve coronavirus ara tırılması. Eurasian Journal of Veterinary Sciences. 23(3-4): 103-106.

7 Chon S.K., Lee H.K. \& Song H.J. 2007. Detection of rotavirus and coronavirus from suckling Korean indigenous calves with acute diarrhea. Korean Journal of Veterinary Service. 30(2): 211-218.

8 Collins J.K., Riegel C.A., Olson J.D. \& Fountein A. 1987. Shedding of enteric coronavirus in adult cattle. American Journal of Veterinary Research. 48(3): 361-365.

9 Crouch C.F. \& Acres S.D. 1984. Prevalence of rotavirus and coronavirus antigens in the feces of normal cows. $\mathrm{Ca}$ nadian Journal of Comparative Medicine. 48(3): 340-342. 
10 Crouch C.F., Bielefeldt Ohmann H., Watts T.C. \& Babiuk L.A. 1985. Chronic shedding of bovine enteric coronavirus antijen-antibody complexes by clinically normal cows. Journal of General Virology. 66(7): 1489-1500.

11 Dringeliene A., Markevieius A., Pukiene V. \& Aeaite J. 2002. Immunity changes in healthy and coronavirus-infected bovine organisms from ecologically different districts. Biologija. (2): 47-52.

12 Dringeliene A., Markevieius A. \& Aeaite J. 2004. Cellular immunity of coronavirus-infected bovine from ecologically different districts of Lithuania. Ekologija. (4): 1-5.

13 Erdogan H.M., Ünver A., Güneș V. \& Çitil M. 2003. Frequency of rotavirus and coronavirus in neonatal calves in Kars district. Kafkas Üniversitesi Veteriner Fakültesi Dergisi. 9(1): 65-68.

14 Fukai K., Sakai T., Fujita K. \& Abe S. 1998. Evaluation of serum neutralizing antibodies to bovine coronavirus in cows \& their calves using Hmlu-1 cells. Indian Journal of Medical Research. 108(7): 8-11.

15 Ganaba R., Belanger D., Dea S. \& Bigras-Poulin M. 1995. A seroepidemiological study of the importance in cowcalf pairs of respiratory and enteric viruses in beef operations from Northwestern Quebec. The Canadian Journal of Veterinary Research. 59(1): 26-33.

16 Hasöksüz M., Kayar A., Dodurka T. \& Ilgaz A. 2005. Detection of respiratory and enteric shedding of bovine coronaviruses in cattle in Northwestern Turkey. Acta Veterinaria Hungarica. 53(1): 137-146.

17 Heckert R.A., Saif L.J., Myers G.W. \& Agnes A.G. 1991. Epidemiologic factors and isotype-specific antibody responses in serum and mucosal secretions of dairy calves with bovine coronavirus respiratory tract and enteric tract infections. American Journal of Veterinary Research. 52(6): 845-851.

18 Jor E., Kristoffersen A., Loken T. \& Jonassen C. 2008. Prevalence of selected viruses in faecal samples from Norwegian dairy and suckler beef calves. Hungarian Veterinary Journal. (130): 228.

19 Kahrs R.F. 2001. Viral Diseases of Cattle. 2nd edn. Ames: Iowa State University Press, pp.127-134.

20 Khan J.A., Khan M.S., Khan M.A., Avais M., Maqbool A., Salman M. \& Rehman Z.U. 2009. Epidemiology of major bacterial and viral causes of diarrheoa in buffalo calves in three districts of the Punjab province of Pakistan. Pakistan Journal of Zoology. (9): 187-193.

21 O'Connor A., Martin S.W., Nagy E., Menzies P. \& Harland R. 2001. The relationship between the occurrence of undifferentiated bovine respiratory disease and titer changes to bovine coronavirus and bovine viral diarrhea virus in 3 Ontario feedlots. Canadian Journal of Veterinary Research. 65(3): 137-142.

22 Okur Gumusova S., Yazıcı Z., Albayrak H. \& Meral Y. 2007. Rotavirus and coronavirus prevalances in healthy calves and calves with diarrhoea. Medycyna Weterynaryjna. 63(1): 62-64.

23 Radostits O.M., Gay C.C., Blood D.C. \& Hinchcliff K.W. 1999. Veterinary Medicine: A Textbook of the Diseases of Cattle, Sheep, Pigs, Goats and Horses. 9th edn. St. Louis: WB Saunders Elsevier, pp.1019-1059.

24 Radostits O.M., Gay C.C., Hinchcliff K.W. \& Constable P.D. 2008. Veterinary Medicine: A Textbook of Diseases of Cattle, Sheep, Pigs, Goats and Horses. 10th edn. London: WB Saunders Company, pp.1286-1297.

25 Reynolds D.J., Morgan J.H., Chanter N., Jones P.W., Bridger J.C., Debney T.G. \& Bunch K.J. 1986. Microbiology of calf diarrhoea in southern Britain. The Veterinary Record. 119(2): 34-39.

26 Rodak L., Babiuk L.A. \& Acres S.D. 1982. Detection by radioimmunoassay and enzyme linked immunosorbent assay of coronavirus antibodies in bovine serum and lacteal secretions. Journal of Clinical Microbiology. 16(1): 34-40.

27 Saif L.J., Redman D.R., Moorhead P.D. \& Theil K.W. 1986. Experimentally induced coronavirus Infections in calves: Viral replication in the respiratory and intestinal tracts. American Journal of Veterinary Research. 47(7): 1426-1432.

28 Saif L.J., Brock K.V., Redman D.R. \& Kohler E.M. 1991. Winter dysentery in dairy herds: electron microscopic and serological evidence for an association with coronavirus infection. The Veterinary Record. 128(19): 447-449.

29 Thomas C.J., Hoet A.E., Sreevatsan S., Wittum T.E., Briggs R.E., Duff G.C. \& Saif L.J. 2006. Transmission of bovine coronavirus and serologic responses in feedlot calves under field conditions. American Journal of Veterinary Research. 67(8): 1412-1420.

30 Tsunemitsu H., Yonemichi H., Hirai T., Kudo T., Oneo S., Mort K. \& Shimizu M. 1991. Isolation of bovine coronavirus from feces and swabs of calves with diarrhea. Journal of Veterinary Medical Science. 53(3): 433-437.

31 Van Metre D.C., Tennant B.C. \& Whitlock R.H. 2008. Infectious disease of the gastrointestinal tract. In: Rebhun's diseases of the dairy cattle. St. Louis, Missouri: Saunders Elsevier, pp.200-295.

32 Wellemans G. \& Opdenbosch E. 1981. Postpartum antibody levels for rota, corona and BVD virus in cows milk. Vlaams Diergeneeskundig Tijdschrift. 50(1): 46-52. 
33 Yang D.K., Kweon C.H., Kim B.H., Park J.K., So B.J. \& Song J.Y. 2007. Serological survey of bovine coronavirus in Korea. Journal of Bacteriology and Virology. 37(2): 105-109.

34 Yıldırım Y., Dagalp S.B., Tan M.T. \& Kalaycioglu A.T. 2008. Seroprevalence of the rotavirus and coronavirus infections in cattle. Journal of Animal and Veterinary Advances. 7(10): 1320-1323. 